\title{
Spatial and Temporal Description of Laboratory Diagnosis of Bovine Rabies in the State of Rio Grande do Sul, Brazil
}

\author{
Carla Rosane Rodenbusch', José Carlos Ferreira', Julio César Almeida da Rosa', Victória Furtado Migliavacca ${ }^{2}$, \\ Angélica Cavalheiro Bertagnolli², Michelle Elias Peres' ${ }^{1}$ \& Laura Lopes de Almeida'
}

\begin{abstract}
Background: Rabies remains one of the most important zoonosis worldwide and in Brazil. In the Brazilian state of Rio Grande do Sul (RS) the disease is one of the main causes of death in bovine herds. The confirmation of suspected rabies cases upon clinical examination depends on specific laboratory diagnosis. The Instituto de Pesquisas Veterinárias Desidério Finamor (IPVDF) is the reference laboratory in RS to diagnose rabies. The objective of the present study was to present a spatial-temporal description of diagnostic procedures of rabies in cattle in the years 2011 to 2015 in RS.

Materials, Methods \& Results: The results of diagnosis procedures of rabies in cattle carried out in the Laboratory of Virology, IPVDF, between January 2011 and December 2015 were listed. Direct immunofluorescence (DIF) and biological assays for confirming rabies cases were used. Cattle population density per area of a municipality, as well as date, species involved, location of suspected case, and diagnosis were obtained from exams and from official rabies record, and input to a spreadsheet file. Spatial distribution maps of cattle rabies confirmed in laboratory and cattle population density per municipality were constructed using the software TerraView 4.2.2 (INPE). In the study period, 998 samples of brains of cattle presenting neurological symptoms compatible with rabies, of which $582(58 \%)$ were confirmed in the laboratory. The frequency of positive cases on a yearly basis varied between 41 and $65 \%$, with statistically lower number of positives in $2011(P>0.05)$. The annual incidence of rabies for a population of 10,000,000 bovines was 33, 88, 112, 108, and 79, respectively, for the years 2011 to 2015, in that order. A positive correlation was observed between the number of samples analyzed and the incidence of positive cases in the study period, and statistically significant difference in incidence between years $(P>0.05)$. Samples were from 175 municipalities, of which $114(65 \%)$ had at least one confirmed rabies case and 61 did not have any. The five municipalities that sent most samples for analysis were Viamão $(n=66)$, Montenegro $(n=$ 40), Camaquã ( $n=39)$, Gravataí $(n=38)$, and São Lourenço do Sul $(n=37)$. The spatial distribution of rabies in cattle in a year did not follow a defined pattern, though most cases confirmed in the laboratory occurred in the greater Porto Alegre region and in southeast RS.

Discussion: High incidence of rabies was observed in 2012 and 2013, and in the two following years the number of cases confirmed in laboratory remained high, compared with 2011. The high incidence of rabies cases confirmed in laboratory correlated with the number of samples analyzed. The fall in vaccine coverage during the study period may also have prompted the increase in suspected cases and in the number of samples examined in the laboratory. A large number of the municipalities presenting rabies cases in cattle was in the greater Porto Alegre region and in southeast RS, which are areas of high and intermediate risk for the disease, according to a previous epidemiological modeling study. The spatial distribution of positive cases was not associated with the cattle population density. The large number of rabies in cattle in RS underscores the importance of the disease and the high risk of exposure, both to humans and animals. The results presented herein may help define control and prevention actions against rabies in RS.
\end{abstract}

Keywords: bovines; epidemiology, laboratory diagnosis, Rio Grande do Sul, rabies. 


\section{INTRODUCTION}

Rabies remains one of the most important diseases worldwide, accounting for approximately 60,000 deaths a year [20]. In Brazil, besides the impact on human health, rabies seriously affects livestock $[14,18]$, and in the state of Rio Grande do Sul (RS) the disease has been considered the main cause of death of cattle [9]. More specifically, in cattle rabies normally takes the clinical paralytic form. The main signs include incoordination, flaccid paralysis of tail, weakness, pelvic limb paralysis, recumbence and convulsions $[6,7,14]$.

Confirmation of clinical suspected cases depends on a laboratory diagnosis. Fragments of brain tissues are submitted to direct immunofluorescence (DIF), whose results are complemented with a biological assay $[2,4,5]$. As the reference center for the diagnosis of rabies in RS, historically most positive diagnoses of rabies made in the Instituto de Pesquisas Veterinárias Desidério Finamor (IPVDF) were in cattle, representing $88.7 \%$ of all analyses carried out from 1985 and 2007 [17]. In addition to the fact that cattle and humans often share the same environment and due to the complexity and epidemiology of rabies, diagnosis of the disease is essential in the process to decide the actions towards prevention and control to be taken against the disease in the several species that are susceptible to it. So, the objective of the present study was to produce a spatial-temporal description of the laboratory diagnosis of cattle rabies in the State of Rio Grande do Sul from 2011 to 2015.

\section{MATERIALS AND METHODS}

\section{Data and inclusion criteria}

This retrospective study was carried out based on an examination of laboratory tests conducted to diagnose rabies in cattle in the Virology Laboratory - IPVDF between January 2011 and December 2015. The information about the requests to diagnose cattle rabies received by the laboratory were retrieved from exam request forms and Rabies Record Book, and included date, species involved, location of the clinical suspicion, and result of laboratory diagnosis. A spreadsheet containing all information collected was created in specific software (Microsoft Excel ${ }^{\mathrm{TM}}$ 2010). Location data included the municipality, since actual geographic coordinates were available in only $60 \%$ of the request forms. The poor infor- mation volume (under 40\%) was observed for the item 'clinical signs' and therefore this category of data was excluded. The search also included cattle population data on a municipality basis, considering the respective area in the calculation of cattle population density. The cattle population used was that officially surveyed in May of each year, during the annual foot-and-mouth disease vaccination campaign (Marcelo Gocks, personal communication, 2016). The area of each municipality was retrieved from the website of the Instituto Brasileiro de Geografia e Estatística (IBGE).

\section{Laboratory diagnosis of rabies}

Suspected rabies cases in cattle were investigated by the Official Veterinary Service. Fresh or frozen brain tissues were sent for analysis and a specific form to report neurological syndrome [12]. In the laboratory, fragments of brain, cerebellum, and medulla tissues were submitted to the direct immunofluorescence antibody (DIF) test for rabies [4]. This assay was complemented with a biological test protocol consisting of intracerebral inoculation of lactating mice $[5,12]$. The results were sent to the Department of Livestock Agriculture and Irrigation (SEAPI) and the Health Secretary of RS. Any sample poorly stored in inappropriate preserving agent or in advanced decay status were excluded.

\section{Spatial distribution}

The spatial distribution maps depicting the laboratory diagnosis of rabies and cattle population density were constructed using the software TerraView 4.2.2 (INPE) [19] based on the geopolitical map of RS (IBGE). One municipality was considered to have positive value when at least one rabies case was diagnosed in cattle and confirmed in the laboratory during the study period. A negative value was attributed to municipalities in which no positive diagnosis of rabies was confirmed in the laboratory.

\section{Statistical analyses}

Based on the notion that rabies is a fatal disease [8], it was assumed that the whole herd was free of rabies, except the cases that were diagnosed positive. Therefore, incidence was calculated using the number of positive cases divided by the bovine population recorded for the same year and adjusted to $10,000,000$ bovines. The effect of the number of 
suspected cases submitted to diagnosis procedures on the actual incidence of rabies was analyzed using the Pearson's linear correlation coefficient, while annual frequencies of positive cases in the 5-year period considered was analyzed using the chi-square test with 0.05 significance level. The analyses were carried out in the software SAS 9.4 with PROC GLM and PROC GENMOD, respectively.

\section{RESULTS}

During the 2011-2015 study period, 998 brain samples of bovines presenting neurological symptoms compatible with rabies were analyzed in IPVDF, of which $582(58 \%)$ were positive for the disease (Table $1)$. The absolute number of diagnostic procedures carried out on an annual basis ranged between 112 and 252, while percent positive cases varied from $41 \%$ to $65 \%$ (Table 1). Frequency of positive cases varied significantly with time, with the lowest values observed in 2011 (Table 1) $[P<0.05]$. Positive linear correlation was observed between the number of positive cases and the number of samples submitted to analysis. The corrected $\mathrm{R}^{2}$ value was 0.97 , while angular coefficient was 0.57 , indicating that the increase by one unit in the number of samples submitted rose incidence by 0.57 (based on a population of 10,000,000 susceptible animals).

Annual incidence of rabies in a population of $10,000,000$ bovines (at $95 \%$ confidence interval) was 33 (24-43), 88 (73-100), 112 (96-131), 108 (92-127), and 79 (66-95), respectively, for the years 2011 to 2015 (Figure 1). Figure 1 also shows the statistical differences in incidence of rabies with time.
The suspected cases analyzed were from 175 municipalities, of which 114 (65\%) had at least one positive case of rabies in the study period. Sixty-one municipalities did not record any rabies case (Table 2 ). In the years 2013 and 2014, the number of municipalities that investigated suspected rabies cases was higher than in the other years. Viamão $(n=66)$, Montenegro ( $\mathrm{n}=40)$, Camaquã $(\mathrm{n}=39)$, Gravataí $(\mathrm{n}=38)$, and São Lourenço do Sul $(n=37)$ were the municipalities that most often submitted samples to analysis in the laboratory during the study period. In turn, the municipalities with the highest occurrence of the disease were Viamão, Gravataí, Montenegro, and Camaquã, with 37, 30,26 , and 25 confirmed cases, respectively. Camaquã was the only municipality to record positive rabies cases in all years during the study period. Canguçu, Caraá, Montenegro, and Triunfo had confirmed positive cases in four years, while Barra do Ribeiro, Candelária, Candiota, Chuvisca, Glorinha, Gravataí, Pelotas, and São Pedro das Missões had positive rabies cases in bovines in three of the five years of the study period.

The spatial distribution of rabies cases confirmed by the IPVDF in the 5-year period is represented in Figure 2A and cattle population density per area of a municipality is shown in Figure 2B. Figure 3 illustrates the number of positive and negative rabies cases per year, and suggests that positive cases scattered during the study period. However, when the whole number of cases in the study period is considered (Figure 2A), it becomes clear that the greater Porto Alegre region and southeast RS were the areas with the highest incidence of rabies, though these do not lodge the largest cattle herds (Figure 2B).

Table 1. Results of the laboratory diagnosis of rabies in cattle performed in the laboratory of Virology, IPVDF, between 2011 and 2015. Different letters indicate statistical difference with 5\% confidence level. $P$ values were corrected for multiple comparisons using the Bonferroni method.

\begin{tabular}{cccc}
\hline Period & Positive & Negative & Total \\
\hline 2011 & $46(41 \%)^{\mathrm{a}}$ & $66(59 \%)$ & 112 \\
2012 & $121(60 \%)^{\mathrm{b}}$ & $82(40 \%)$ & 203 \\
2013 & $155(65 \%)^{\mathrm{b}}$ & $85(35 \%)$ & 240 \\
2014 & $150(60 \%)^{\mathrm{b}}$ & $102(40 \%)$ & 252 \\
2015 & $110(58 \%)^{\mathrm{b}}$ & $81(42 \%)$ & 191 \\
2011 to 2015 & $582(58 \%)^{\mathrm{b}}$ & $416(42 \%)$ & 998 \\
\hline
\end{tabular}


Table 2. Results of the laboratory diagnosis of rabies in cattle performed in the laboratory of Virology, IPVDF, between 2011 and 2015 considering the municipality where suspected cases were observed.

\begin{tabular}{cccc}
\hline Period & Positive & Negative & Total \\
\hline 2011 & $15(37 \%)$ & $26(63 \%)$ & 41 \\
2012 & $28(57 \%)$ & $21(43 \%)$ & 49 \\
2013 & $52(64 \%)$ & $29(36 \%)$ & 81 \\
2014 & $49(64 \%)$ & $27(36 \%)$ & 76 \\
2015 & $42(61 \%)$ & $27(39 \%)$ & 69 \\
2011 to 2015 & $114(65 \%)$ & $61(35 \%)$ & 175 \\
\hline
\end{tabular}

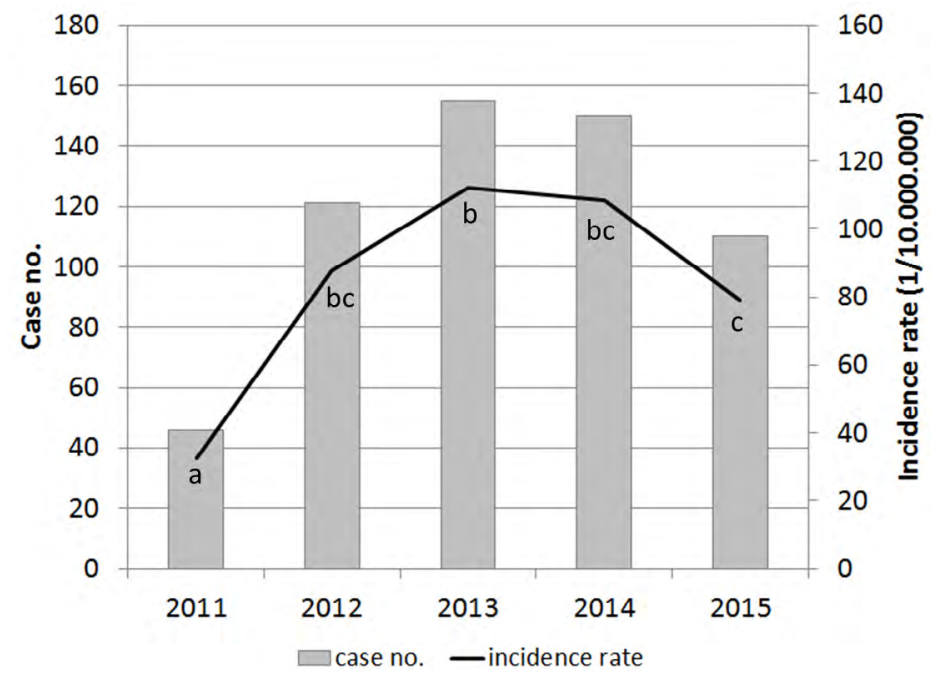

Figure 1. Number of positive rabies cases confirmed in laboratory and incidence of the disease in 10,000,000 bovines between 2011 and 2015. Different letters in the same column indicate statistical difference with $5 \%$ significance level.
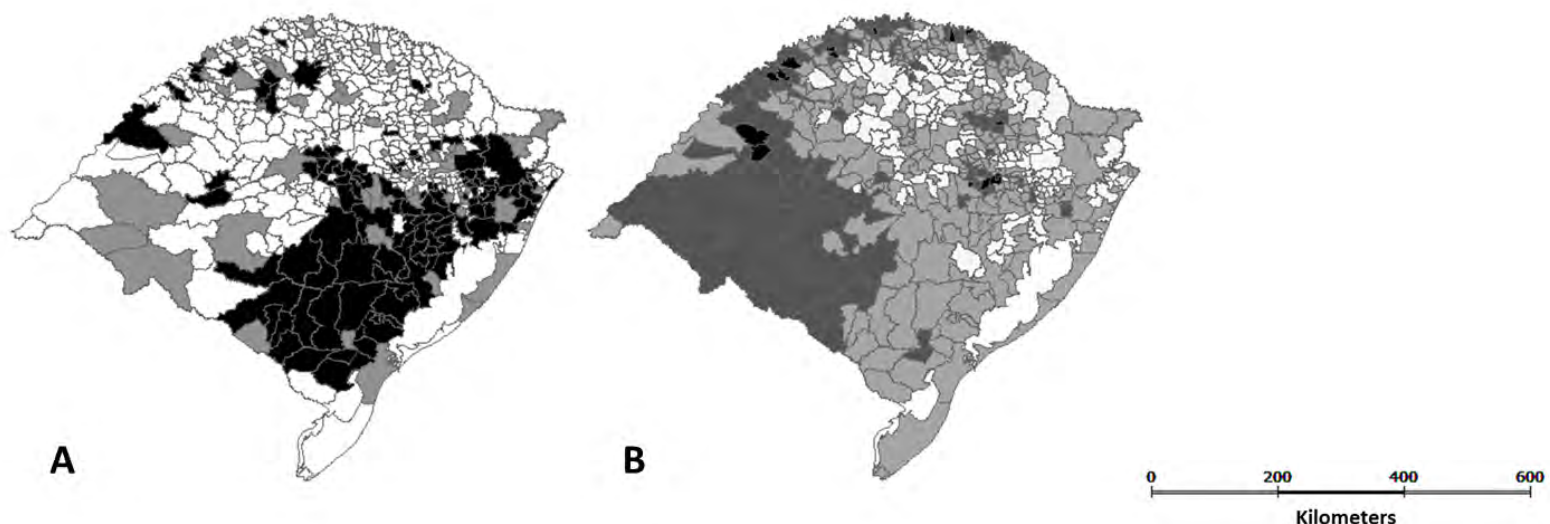

Figure 2. Spatial distribution of laboratory diagnosis of rabies and spatial density of cattle in RS. A- Spatial distribution of the diagnosis of rabies in bovines carried out in the Laboratory of Virology, IPVDF, between 2011 and 2015. Black areas indicate the municipalities where at least one rabies case was diagnosed in cattle; grey areas indicate the municipalities where no positive rabies case was confirmed in the laboratory; white areas show the municipalities that did not send biological material for analysis during the study period. B- Distribution of cattle population density per area of a municipality. White areas indicate up to 30 bovines $/ \mathrm{km} 2$; light grey areas indicate between 31 and 62 bovines $/ \mathrm{km}^{2}$; dark grey areas indicate between 63 and 93 bovines $/ \mathrm{km}^{2}$; black areas indicate over 94 bovines $/ \mathrm{km}^{2}$ 


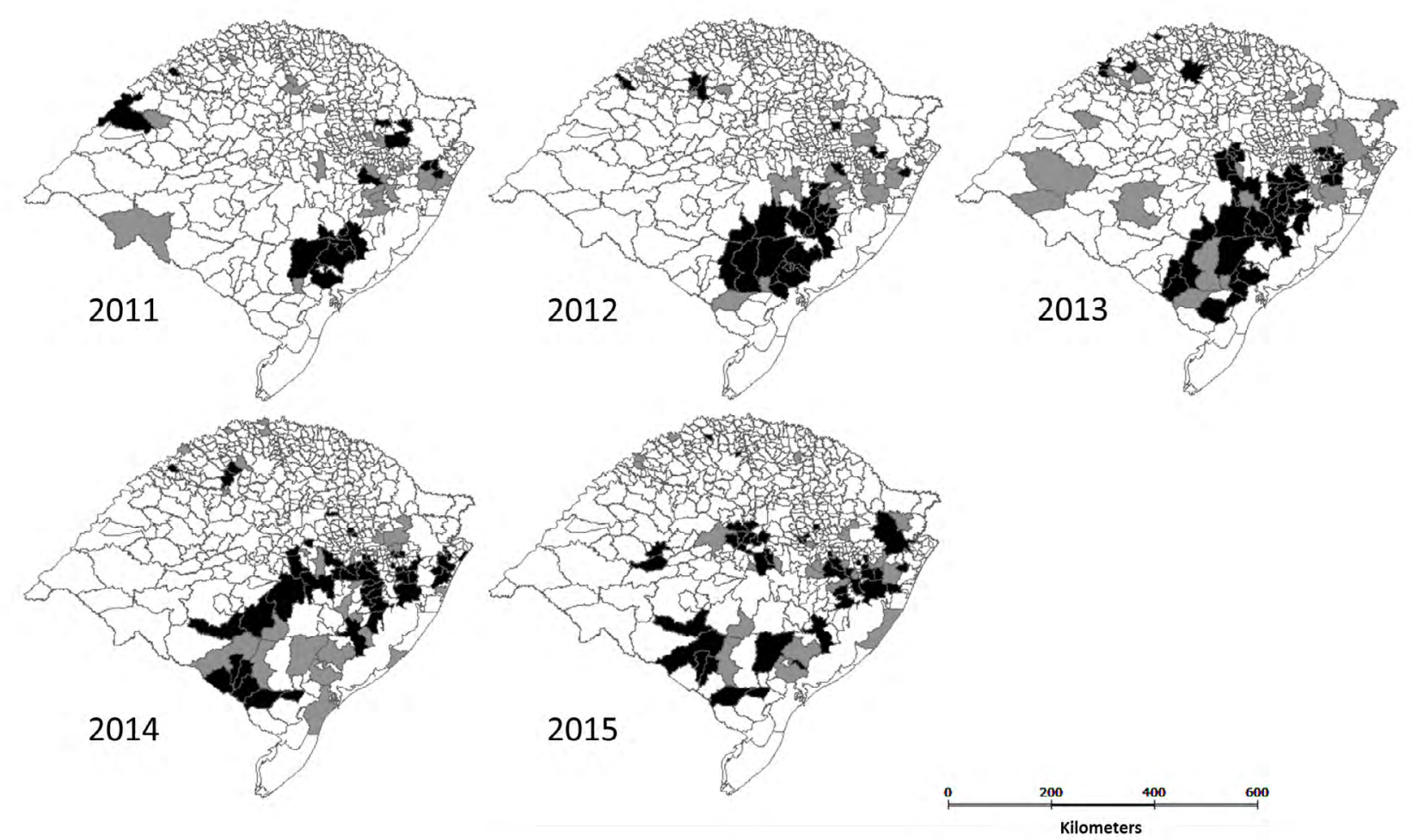

Figure 3. Annual spatial distribution of laboratory diagnosis of rabies cases carried out in the Laboratory of Virology, IPVDF, between 2011 and 2015. Black areas indicate the municipalities where at least one rabies case was diagnosed in cattle; grey areas indicate the municipalities where no positive rabies case was confirmed in the laboratory; white areas show the municipalities that did not send biological material for analysis during the study period.

\section{DISCUSSION}

Higher frequency of positive rabies cases were observed in 2012 and 2014 in RS, compared with 2011. Annual incidence observed during the period varied significantly (Figure 1), and a correlation was observed between the number of samples submitted to analysis and incidence of rabies $(P<0.05)$. It is believed that rabies in herbivores in South America manifests as cyclic outbreaks every 3 to 7 years [1], but it is not possible to attribute the rise in occurrence to the cyclic character of outbreaks because the study period was comparatively short. Despite that, it is known that the rise in diagnostic procedures starting in 2012 is a result of the effort by SEAPI to improve the number of official records [9]. Since an increase in the number of samples submitted to analysis indicates an increase in positive cases, our results underline the importance of control programs, admitting that the higher the number of submitted samples, the more sensitive will be the control of the disease. At any rate, it should be highlighted that the high occurrence of rabies in cattle in RS recorded in $2013(n=155)$ was only second to the historic record of 240 cases reported in 1984 [15]. On the other hand, effective vaccination coverage is an important factor in rabies epidemiology, since vaccines lend immunity to exposed bovines [8]. It is possible that the reduction in the number of bovines that were vaccinated against rabies in Brazil between 2009 and 2012 as reported in official bulletins issued by the Livestock and Agricultural Ministry of Brazil [13] may have contributed to the increase in the incidence in $\mathrm{RS}$ during the study period.

Despite the high incidence of rabies in recent years, it is believed that only a small part of the clinical suspected cases of rabies in bovine herds are confirmed in a laboratory [17]. Considering that RS has over 10 million bovines [Marcelo Gocks, personal communication, 2016], the analysis of 998 suspected cases in a laboratory (Table 1) might be seen as a low number in light of the importance of the disease, although $70 \%$ of all compulsory records of rabies in cattle in RS in 2011 and 2012, according to the Official Veterinary Service of RS [9]. Laboratory confirmation is hampered by problems like the inappropriate conservation of samples and cultural 
issues such as the investigation of the index case and the subsequent extrapolation of diagnosis to the similar clinical suspicions [17]. Another important factor that may affect laboratory confirmation is the distance between the farm and laboratory facilities. This relationship was not contemplated in the present study, but a previous study conducted in Rio de Janeiro state, Brazil, did not find any correlation between the number of samples analyzed and distance between farms and laboratories [10].

Another relevant issue is the fact that $42 \%$ of the samples analyzed were negative for rabies (Table 1). Of these, only the samples collected from cattle herds surveilled for transmissible bovine spongiform encephalopathies (BSE) were sent to the reference laboratory of MAPA for laboratory exams to detect BSE and differential diagnosis [11]. Considering that in RS other important diseases affect the central nervous systems of bovines, such as cerebral babesiosis, hepatic encephalopathy due to the consumption of Senecio spp., poisoning by Solanum fastigiatum, meningoencephalitis caused by bovine herpesvirus, malignant catarrhal fever, and polioencephalomalacia [14], the other samples that were negative for rabies also had to undergo complementary laboratory exams to determine other possible causes of neurological syndromes.

An interesting finding regards spatial distribution of rabies cases: the municipalities that sent the largest numbers of biological material for analysis in the laboratory were those that also presented the highest numbers of confirmed cases in the study period. Rabies in cattle was confirmed mainly in the greater Porto Alegre region and in southeast RS (Figure 1A), which are not the areas with the largest herds (Figure 1B). These results agree with the findings published in other studies, which did not report any direct relationship between cattle population density and occurrence of rabies $[3,9]$. It should be remembered that rabies epidemiology is complex, that the disease is caused by a virus whose main reservoirs are bat species. It is known that populations of Desmondus rotundus, the main vector of rabies to cattle is influenced by the availability of shelter such as caves and roofs, in addition to food resources - more specifically, cattle herds [3]. The poor record of such shelters to bats in the greater Porto Alegre region has been highlighted as one of the possible reasons for the high incidence of rabies in the region, since population control surveys depend on reliable information on this aspect [9].

The results reported herein agree with the epidemiological modeling of rabies in cattle, which classified the greater Porto Alegre region and southeast RS as high and intermediate risk zones for rabies [3]. Such classification took into account the concepts of receptivity and vulnerability of the region in order to assign risk figures to a given municipality. Receptivity represents the capacity of the ecosystem to support populations of hematophagous bats due to the availability of shelter and food resources, while vulnerability is linked with the circulation of the rabies virus in a region and the possibility that it may spread to adjacent areas $[3,12]$. Other factors that increase rabies spread include anthropic actions that influence bat ecology [16] and point climate changes [9], though these variables have not yet been investigated in RS.

The large number of rabies in cattle confirmed in laboratory in RS underscores the economic importance of the disease and warns of the high risk of exposure to both humans and animals. The results described in the present study may be used to help plan, control, and prevent rabies in RS.

\section{CONCLUSION}

RS had high incidence of rabies diagnosed in laboratory between 2012 and 2015. Starting in 2012, the number of rabies cases in cattle increased considerably, just like the number of biological samples analyzed. The years 2012 and 2013 were those when most cases were confirmed. The greater Porto Alegre region and southeast RS had the highest number of cases confirmed in laboratory. The distribution of rabies in cattle did not correlate with bovine population density in RS.

Acknowledgements. Carla Rosane Rodenbusch has a postdoc grant offered by CAPES in the Programa de Pós graduação em Saúde Animal (IPVDF). The authors are grateful to Eduardo de Freitas Costa (UFRGS) for help and statistical review of data.

Declaration of interest. The authors report no conflicts of interest. The authors alone are responsible for the content and writing of the paper. 


\section{REFERENCES}

1 Barros C.S.L., Driemeier D., Dutra I.S. \& Lemos R.A.A. 2006. Doenças do sistema nervoso de bovinos no Brasil. São Paulo: Vallé, 207p.

2 Batista H.B.C.R., Franco A.C. \& Roehe P.M. 2007. Raiva: uma breve revisão. Acta Scientiae Veterinariae. 35(2): 125-144.

3 Braga G.B., Grisi-Filho J.H.H., Leite B.M., Sena E.F. \& Dias R.A. 2014. Predictive qualitative risk modelof bovine rabies occurrence in Brazil. Preventive Veterinary Medicine. 113: 536-546.

4 Dean D.J., Abelseth M.K. \& Atanasiu P. 1996. The fluorescent antibody test. In: Meslin F.X., Kaplan M.M. \& Koprowski H. (Eds). Laboratory techniques in rabies. 4th edn. Geneva: World Health Organization, pp.88-93.

5 Koprowski H. 1996. The mouse inoculation test. In: Meslin F.X., Kaplan M.M. \& Koprowski H. (Eds). Laboratory techniques in rabies. 4th edn. Geneva: World Health Organization, pp.80-86.

6 Langorh I.M., Irigoyen L.F., Lemos R.A.A. \& Barros C.S.L. 2003. Aspectos epidemiológicos, clínicos e distribuição das lesões histológicas no encéfalo de bovinos com raiva. Ciência Rural. 33(1): 125-131.

7 Lima E.F., Riet-Correa F., Castro R.S., Gomes A.A.B. \& Lima F.S. 2005. Sinais clínicos, distribuição das lesões no sistema nervoso e epidemiologia da raiva em herbívoros na região Nordeste do Brasil. Pesquisa Veterinária Brasileira. 25(4): 250-264.

8 MacLachlan N.J. \& Dubovi E.J. 2011. Rhabdoviridae. In: Fenner's Veterinary Virology. London: Academic Press, pp.327-341.

9 Martinez B.A.F., Costa E.F., Machado G., Hein H.E., Medeiros A.A.R. \& Correa A.M.R. 2013. Notificações de doenças de bovinos recebidas pelo Serviço Veterinário Oficial do Rio Grande do Sul nos anos de 2011 e 2012. A Hora Veterinária. 32(192): 28-33.

10 Martins V.B., Oliveira F.G., Dia A.V.A.B. \& Moreira W.C. 2015. Avaliação do diagnóstico laboratorial do programa de controle da raiva urbana no Rio de janeiro, Brasil entre 2002 e 2011. Vigilância sanitária em debate. 3(3):56-63.

11 Ministério da Agricultura, Pecuária e Abastecimento. 2008. Encefalopatia espongiforme bovina - EEB: doença da vaca louca. Secretaria de Defesa Agropecuária. Brasília. 24p. Disponível em: <http://www.agricultura.gov.br/arq_editor/file/Aniamal/programa\%20nacional\%20dos\%20herbivoros/Cartilha\%20t\%C3\%A9cnica\%20EEB\%202008.pdf.> [Accessed online March 2016].

12 Ministério da Agricultura, Pecuária e Abastecimento. 2009. Controle da raiva dos herbívoros : manual técnico 2009. Secretaria de Defesa Agropecuária. Brasília. 124 p. Disponível em: <http://www.agricultura.gov.br/arq_editor/ file/Aniamal/programa\%20nacional\%20dos\%20herbivoros/manual\%20tecnico\%20para\%20controle\%20da\%20raiva. pdf.> [Accessed online March 2016].

13 Ministério da Agricultura, Pecuária e Abastecimento. 2016. Ações de controle da raiva dos herbívoros no Brasil. Divisão de Epidemiologia / Departamento de Saúde Animal. 4p. Disponível em: <http://www.agricultura.gov.br/arq_editor/ file/Aniamal/programa\%20nacional\%20dos\%20herbivoros/Dados\%20controle\%20raiiva\%20herb\%C3\%ADvoros\%20 Brasil\%20ate\%202012.pdf>. [Accessed online March 2016].

14 Rissi D.R., Pierezan F., Oliveira-Filho J.C., Lucena R.B., Carmo P.M.S. \& Barros C.S.L. 2010. Abordagem diagnóstica das principais doenças do sistema nervoso de ruminantes e equinos no Brasil. Pesquisa Veterinária Brasileira. 30(11): 958-967.

15 Roehe P.M., Cunha A.C., Rodrigues R.R., Gonçalves A.R. \& Ribeiro C.L.G. 1987. Diagnóstico laboratorial da raiva no Rio Grande do Sul, Brasil. Boletin de la oficina sanitária panamericana. 102(5): 464-474.

16 Silva J.A., Moreira E.C., Haddad J.P.A., Sampaio I.B.M., Modena C.M. \& Tubaldini M.A.S. 2001. Uso da terra como determinante da distribuição da raiva bovina em Minas Gerais, Brasil. Arquivo Brasileiro de Medicina Veterinária e Zootecnia. 53(3): 273-283.

17 Teixeira T.F., Holz C.L., Caixeta S.P.M.B., Dezen D., Cibulski S.P., Silva J.R., Rosa J.C.A., Schmidt E., Ferreira J.C., Batista H.B.C.R., Caldas E., Franco A.C. \& Roehe P.M. 2008. Diagnóstico de raiva no Rio Grande do Sul, Brasil, de 1985 a 2007. Pesquisa Veterinária Brasileira. 28(10): 515-520. 
18 Teixeira L.H.M., Tomaz L.A.G., Linhares G.F.C., Santos M.F.C. \& Jayme V.S. 2015. Distribuição espaço-temporal dos diagnósticos laboratoriais da raiva animal. Ciência Animal Brasileira. 16(1): 144-157.

19 TerraView 4.2.2. 2010. São José dos Campos, SP: INPE. Disponível em: <http://www.dpi.inpe.br/terraview>. [Accessed online January 2016].

20 World Health Organization. 2015. Human rabies. Disponível em: <http://www.who.int/rabies/home_human_rabies/ en/>. [Accessed online March 2016]. 